\title{
Use of systemic fungicides combined with multisite to control of asian rust and soybean yield
}

\author{
Aline Netto ${ }^{1}$, Deivid Sacon ${ }^{2}$, Alessandra Gallina ${ }^{3}$, Michele Fochesatto ${ }^{3}$, Francine Spitza Stefanski ${ }^{3}$, Paola \\ Mendes Milanesi ${ }^{3}$ \\ ${ }^{1}$ Grupo ABC Agrícola. ${ }^{2}$ Universidade Federal de Viçosa, UFV, Viçosa, MG. ${ }^{3}$ Universidade Federal da Fronteira Sul, UFFS, \\ campus Erechim, RS. E-mail: paola.milanesi@uffs.edu.br
}

\begin{abstract}
Asian soybean rust is an aggressive disease and chemical control must be handled assertively to minimize productivity damage. The objective was to evaluate systemic fungicides and multisite mancozeb, combined or not, and the effects on disease control and soybean yield, cv. 'BMX Lança'. The work was conducted in the field in the 2016/17 and 2017/18 crops, in a randomized complete block design, with four replications. The following treatments were evaluated: $T+P$ ) trifloxystrobin + prothioconazole; $A+B$ ) azoxystrobin + benzovindiflupyr; $\mathrm{T}+\mathrm{P}+\mathrm{MB}$ ) trifloxystrobin + prothioconazole + mancozeb; $\mathrm{A}+\mathrm{B}+\mathrm{MB}$ ) azoxystrobin + benzovindiflupyr + mancozeb; $\mathrm{MB}$ ) mancozeb; and Control (without fungicide application). After the occurrence of the first symptoms of the disease, the severity (\%) was evaluated in five trifolia per plot, every seven days, making it possible to calculate the area under the disease progress curve (AUDPC). The yield components and productivity ( $\mathrm{kg} \mathrm{ha}^{-1}$ ) were also evaluated. In both crops, the combination of systemic fungicides and mancozeb reduced the severity (\%) and progress of Asian rust, reaching a control above $81 \%$. Treatment with trifloxystrobin + prothioconazole + mancozeb $(T+P+M B)$ obtained the highest percentages of control (94.5\% - 2016/17, and 93.7\% - 2017/18) of Asian rust, and provided, in the 2016/17 crop, productivity at $15 \mathrm{sc} \mathrm{ha}^{-1}$, in relation to the fungicide applied alone $(\mathrm{T}+\mathrm{P})$. The combination of systemic fungicides and mancozeb, as proposed in this work, reduces the severity and progress of Asian rust and ensures the maintenance of the productive potential of the soybean.
\end{abstract}

Keywords: AUDPC; chemical control; Glycine max (L.) Merril; thousand grain weight; Phakopsora pachyrhizi (Sydow \& Sydow).

\section{Uso de fungicidas sistêmicos combinados a multissítio para o controle da ferrugem asiática e efeitos sobre a produtividade da soja}

\section{Resumo}

A ferrugem asiática da soja é uma doença agressiva e o controle químico deve ser manejado assertivamente, para minimizar danos sobre a produtividade. Objetivou-se avaliar fungicidas sistêmicos e o multissítio mancozeb, combinados ou não, e os efeitos sobre o controle da doença e a produtividade da soja, Cv. 'BMX Lança'. O trabalho foi conduzido à campo nas safras 2016/17 e 2017/18, em delineamento de blocos ao acaso, com quatro repetições. Foram avaliados os tratamentos: $T+P$ ) trifloxistrobina + protioconazol; $\mathrm{A}+\mathrm{B}$ ) azoxistrobina + benzovindiflupyr; $\mathrm{T}+\mathrm{P}+\mathrm{MB}$ ) trifloxistrobina + protioconazol + mancozeb; $\mathrm{A}+\mathrm{B}+\mathrm{MB}$ ) azoxistrobina + benzovindiflupyr + mancozebe; $\mathrm{MB}$ ) mancozeb; e Testemunha (sem aplicação de fungicidas). Após o surgimento dos primeiros sintomas da doença, a severidade (\%) foi avaliada em cinco trifólios por parcela, a cada sete dias, possibilitando o cálculo da área abaixo da curva de progresso da doença (AACPD). Avaliou-se também os componentes de rendimento e a produtividade ( $\left.\mathrm{kg} \mathrm{ha}^{-1}\right)$. Em ambas as safras, a combinação entre fungicidas sistêmicos e o mancozeb reduziu a severidade (\%) e o progresso de ferrugem asiática, atingindo um controle acima de $81 \%$. O tratamento com trifloxistrobina + protioconazol + mancozeb (T+P+MB) obteve os maiores percentuais de controle $(94,5 \%-2016 / 17$; e $93,7 \%$ - 2017/18) da ferrugem asiática, e proporcionou, na safra 2016/17, produtividade superior em $15 \mathrm{sc} \mathrm{ha-1}$, em relação ao fungicida aplicado isoladamente $(T+P)$. A combinação entre fungicidas sistêmicos e mancozeb, conforme proposto nesse trabalho, reduz a severidade e o progresso da ferrugem asiática e 
assegura a manutenção do potencial produtivo da soja.

Palavras-chave: AACPD; controle químico; Glycine max (L.) Merril; peso de mil grãos; Phakopsora pachyrhizi (Sydow \& Sydow).

\section{Introduction}

Considered the most important soybean disease, Asian rust has as its etiological agent the fungus Phakopsora pachyrhizi Sydow \& Sydow, whose damage may lead to reductions above $80 \%$ of productivity, being this pathogen characterized as of high biological plasticity and easy dissemination (GODOY et al., 2016; FIGUEIREDO et al., 2019). Asian rust reduces the photosynthetic efficiency of soybean to the detriment of coalescence of pustules in the leaf surface (EMBRAPA, 2014), and the control of this disease is essential for the agricultural landscape of soybean (REIS et al., 2019).

In the seasons following the first detection of Asian rust in Brazil, disease control was realized only with systemic action fungicides, mainly with sterol demethylation inhibitors (DMIs - triazoles). However, in 2007, cases of loss of efficiency of this group of fungicides were observed due to its excessive use, which led to the selection of resistant pathogen populations (SCHMITZ et al., 2014; LEMES et al., 2015).

Thus, was started the recommendation of DMls combined with quinone outside inhibitors (Qols - strobilurins), but in recent crops these fungicides have demonstrated a gradual loss of efficiency. Some double or triple mixtures, involving fungicides that combine DMIs, Qols and succinate dehydrogenase inhibitors (SDHIs carboxamides) have emerged as a possibility of Asian rust control, but the pathogen resistance to this combination of fungicides has been reported (GODOY et al., 2016; KLOSOWSKI et al., 2016; LANGENBACH et al., 2016; FRAC, 2017).

The difficulty in controlling Asian rust with fungicides is becoming increasingly evident, proving the high adaptability of the etiological agent (SILVA et al., 2015). In this sense, the combination between systemic fungicides (site specific) and multisite action arises as a possibility to increase the control efficiency for this plant pathology (KNEBEL et al., 2019).

Multisites act by means of different mechanisms of action, such as inactivation of sulfhydryl groups (-SH) in amino acids and enzymes on fungal cell, resulting in disruption of lipid metabolism, respiration, and ATP production (REIS et al., 2016). In addition, this group of fungicides reduces the severity of the disease and the risk of selection of pathogen-resistant populations to these active ingredients (AZEVEDO, 2015).

In cooperative trials conducted in several Brazilian states in the 2015/16 crop, it was found that systemic fungicides associated with multisites, provided an increase of up to $63 \%$ in the control of Asian soybean rust (EMBRAPA, 2016a). Thus, the present work aimed to evaluate the efficiency of the combination of systemic fungicides and multisite on the progress and the control of Asian soybean rust, and the effect of these treatments on crop yield.

\section{Material and Methods}

The experiment was conducted in Erechim-RS $\left(27^{\circ} 43^{\prime} 29.00^{\prime \prime}\right.$ S, $52^{\circ} 17^{\prime} 41.00^{\prime \prime} \mathrm{W}$, altitude: $753 \mathrm{~m}$ ), in the $2016 / 17$ and $2017 / 18$ crops. The soil is a Red Latosol Aluminoferric humic - Oxisol (EMBRAPA, 2018). According to classification system established by Köeppen, the climate is Cfa type (temperate humid with hot summer), with rainfall distributed throughout the year (MATZENAUER et al., 2011). Soil samples were collected at depth of up to $0.10 \mathrm{~m}$ and the following chemical properties determined: $\mathrm{pH}$ : 5.4; organic matter (OM): 3.6\%; P: $5.7 \mathrm{mg} \mathrm{dm}^{-3} ; \mathrm{K}$ : $89 \mathrm{cmol}_{\mathrm{c}} \mathrm{dm}^{-3}$; Al: $0.2 \mathrm{cmol}_{\mathrm{c}} \mathrm{dm}^{-3}$; Ca: $5.6 \mathrm{cmol}_{\mathrm{c}}$ $\mathrm{dm}^{-3} ; \mathrm{Mg}: 2.8 \mathrm{cmol}_{\mathrm{c}} \mathrm{dm}^{-3}$; and Cation Exchange Capacity (CEC): $14.2 \mathrm{cmol}_{\mathrm{c}} \mathrm{dm}^{-3}$.

The soybean cultivar used in both crops was 'BMX Lança' (maturity cycle 5.8; undetermined growth). The experiment was conducted in a no-tillage system with wheat as a predecessor crop. The experimental design was randomized blocks (RBD) with 6 treatments and 4 replications, totalizing 24 experimental units, with dimensions of $18 \mathrm{~m}^{2}$ ( $3 \mathrm{~m}$ width $\times 6 \mathrm{~m}$ length).

The treatments used were: $\mathrm{T}+\mathrm{P}$ (trifloxystrobin + prothioconazole; $75+87.5 \mathrm{~g}$ a.i.ha ${ }^{-1}$ ); A + B (azoxystrobin + benzovindiflupyr; 
$90+45$ g a.i.ha $\left.{ }^{-1}\right) ; \mathrm{T}+\mathrm{P}+\mathrm{Mb}$ (trifloxystrobin + prothioconazole + mancozeb; $75+87.5+1870 \mathrm{~g}$ a.i.ha ${ }^{-1}$ ); $\mathrm{A}+\mathrm{B}+\mathrm{Mb}$ (azoxystrobin + benzovindiflupyr + mancozeb; $90+45+1870 \mathrm{~g}$ a.i.ha ${ }^{-1}$ ), Mb (mancozeb; +1870 g a.i.ha ${ }^{-1}$ ); and Control (absence of fungicidal application). The adjuvant dose followed the manufacturer's recommendation for each fungicide.

The fungicides were applied with the help of a $\mathrm{CO}_{2}$ pressurized costal sprayer with a constant pressure of $29.0 \mathrm{Psi}$, resulting in a constant flow rate of $150 \mathrm{~L} \mathrm{ha}^{-1}$, with TXA $8002 \mathrm{VK}$ conical nozzles spaced $0.5 \mathrm{~m}$ apart, and at a constant velocity of approximately $1 \mathrm{~m} \mathrm{~s}^{-1}$. These applications were realized at stages V6, R1, R5.1 and R6.

To verify the efficiency of the fungicides in the control of Asian rust, after the onset of the first symptoms, the disease severity was evaluated in five leaf samples (trifoliate leaves) per parcel every seven days, and these were compared with the diagrammatic scale of Godoy et al. (2006). From the information obtained through the severity scale, the area under the disease progress curve (AUDPC) was determined, whose values were calculated according to the equation proposed by Campbell and Madden (1990).

Harvesting was performed when all plants no longer had green leaves, considering a useful area of $4.0 \mathrm{~m}^{2}$ per parcel. For this, a plot stationary threshing was used. The yield components for each treatment were quantified considering the number of pods per plant, from a sample of ten plants per plot, randomly collected at harvest, and the thousand grains weight. Grain moisture (\%) was determined by the oven method at $105{ }^{\circ} \mathrm{C}$ (BRASIL, 2009) and, subsequently, the values were corrected to $13 \%$.
Then, these values were added to the total grain weight of each treatment, in order to obtain the total yield $\left(\mathrm{kg} \mathrm{ha}^{-1}\right)$.

The data obtained were subjected to analysis of variance by the $F$ test $(p \leq 0.05)$ and, when significant, the Tukey test $(p \leq 0.05)$ was applied to compare averages. The analyzes were performed with the support of SISVAR version 5.6 statistical software (FERREIRA, 2011).

\section{Results and Discussion}

All treatments evaluated in this study and that included fungicide application, showed severity of Asian soybean rust lower than the control (Figure 1). For the 2016/17 crop, during the 29 days (03/12/2017) of evaluation, the disease progression in the control treatment reached $80 \%$ (Figure 1A), followed by intense defoliation of the plants. However, in the other treatments, there were still trifoliate leaves.

In the 2017/18 crop, the severity of Asian rust was lower, noting that the disease progression in the control treatment reached $70 \%$ of severity only at the end of the crop cycle (Figure 1B). In this case, the low initial inoculum pressure may have contributed to a better fungicide efficiency compared to the previous crop.

The increase in severity of Asian rust during the crop is determined by environmental factors, including night temperature (between 18 and $26.5{ }^{\circ} \mathrm{C}$ ), continuous leaf wetness and constant rainfall (EMBRAPA, 2013b; MINCHIO et al., 2018). In the present study, Asian rust was late diagnosed in both seasons, that is, in the first half and at the end of February for the 2016/17 and 2017/18 crops, respectively (Figure 1). 
Figure 1. Severity (\%) of Asian soybean rust, cv. 'BMX Lança', according to the application of systemic fungicides, combined or not with the multisite mancozeb, in the 2016/17 (A) and 2017/18 (B) crop seasons.

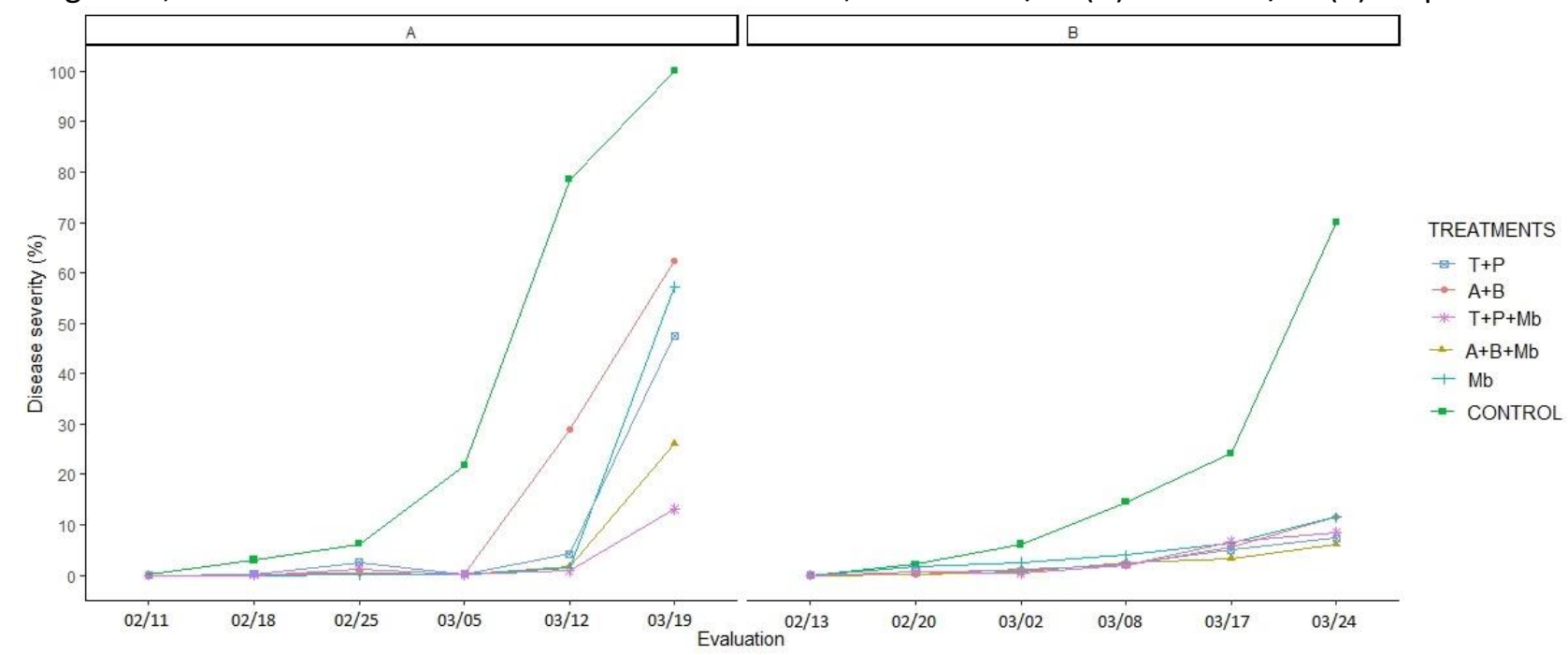

On treatments with fungicides combined with mancozeb $(T+P+M b$ and $A+B+M b)$ showed the lowest disease severity. Similar to this result, the use of systemic fungicides combined with the multisite mancozeb provided lower severity of Asian rust $(27 \%$ to $30 \%)$, plus an increase in control of up to 63\% (EMBRAPA, 2016a). The sporulation of Phakopsora pachyrhizi occurs daily when in contact with the host and thus, according to prevailing crop environmental conditions, fungicide applications tend to slow the progress of Asian rust. However, there may be variations depending on the protective or curative effect of each fungicide, beyond the time of application (EMBRAPA, 2016b).

For the area under the disease progress curve (AUDPC) and the control (\%), systemic fungicides combined or not with mancozeb multisite achieved greater efficiency in Asian rust control, differing of the control treatment in both seasons (Table 1 ).

Table 1. Area under the disease progress curve (AUDPC) and control (\%) of Asian soybean rust, cv. 'BMX Lança', according to the application of systemic fungicides, combined or not with multisite mancozeb, in the 2016/17 and 2017/18 crop seasons.

\begin{tabular}{lrrrr}
\hline \multirow{2}{*}{\multicolumn{1}{c}{ Treatments }} & \multicolumn{4}{c}{ Crop Season } \\
\cline { 2 - 5 } & \multicolumn{2}{c}{$2016 / 17$} & $2017 / 18$ & $2016 / 17$ \\
\cline { 2 - 5 } & \multicolumn{2}{c}{ AUDPC } & \multicolumn{2}{c}{ Control (\%) } \\
\hline Trifloxystrobin + prothioconazole & $218.1 \mathrm{cA}^{1}$ & $57.9 \mathrm{bB}$ & $80.4 \mathrm{abA}$ & $89.7 \mathrm{aA}$ \\
Azoxystrobin + benzovindiflupyr & $426.1 \mathrm{bA}$ & $103.2 \mathrm{bB}$ & $61.8 \mathrm{bB}$ & $81.7 \mathrm{aA}$ \\
Trifloxistrobin + prothioconazole + mancozeb & $60.9 \mathrm{cA}$ & $35.3 \mathrm{bA}$ & $94.5 \mathrm{aA}$ & $93.7 \mathrm{aA}$ \\
Azoxystrobin + benzovindiflupyr + mancozeb & $111.9 \mathrm{cA}$ & $84.4 \mathrm{bA}$ & $89.9 \mathrm{aA}$ & $85.0 \mathrm{aA}$ \\
Mancozeb & $211.5 \mathrm{cA}$ & $137.5 \mathrm{bA}$ & $81.0 \mathrm{abA}$ & $75.7 \mathrm{aA}$ \\
Control & $1116.3 \mathrm{aA}$ & $566.7 \mathrm{aB}$ & $0.0 \mathrm{cA}$ & $0.0 \mathrm{bA}$ \\
\hline
\end{tabular}

\begin{tabular}{lcc}
\hline C.V. $(\%)^{2}$ & 36.9 & 15.9 \\
${ }^{1}$ Averages followed by the same lowercase letter in the column (seasons) and uppercase letter in the row (between
\end{tabular} seasons) do not differ significantly from each other by the Tukey test $(p \leq 0.05) .{ }^{2}$ Coefficient of variation.

In terms of the control of Asian rust, in the $2017 / 18$ crop there was a more pronounced effect of the treatments, which showed greater control than in the previous crop (Table 1). This indicates the relation of the progress of the disease with the different environmental conditions observed in both harvests. In the treatment with trifloxystrobin + prothioconazole 
+ mancozeb $(\mathrm{T}+\mathrm{P}+\mathrm{Mb})$ there was a control increase of $14.1 \%$ when compared to its use separately (T+P) in the $2016 / 17$ crop (Table 1 ). These results reinforce the importance of adopting practices involving the combination of systemic and multisite fungicides in the preventive treatment of this pathology (KNEBEL et al., 2019).

After verifying differences in the sensitivity of two populations of Phakopsora pachyrhizi to systemic fungicides, Juliatti et al. (2017) concluded that the combination of them with multisites, such as mancozeb, should be considered as essential in the management of Asian soybean rust, given the reduced efficiency of active ingredients such as strobilurins, triazoles and carboxamides. It is noteworthy that DMIs and Qols are fungicides that have high risk for the development of resistance in phytopathogens and, therefore, their use alone is not recommended, as occurred with the fungicide tebuconazole, whose efficiency was gradually reduced from $90 \%$ to $24 \%$, in ten harvests (EMBRAPA, 2013a).

When the pathogen enters in the host, plant metabolism is programmed to activate defense mechanisms, thus, decreasing photosynthetic activity and $\mathrm{CO}_{2}$ absorption, which can lead to flower and pod abortion (TAIZ; ZEIGER, 2013). In this context, it was verified the effect of harvests and of the severity of Asian soybean rust, about the variables related to yield and yield components, whereby, for both harvests, no statistical difference was observed for the number of pods per plant (Table 2).

Similarly, for the thousand grains weight $(\mathrm{g})$, in the 2016/17 crop, there was no difference between treatments with fungicide application (systemic, with and without mancozeb) and the control (Table 2). However, all treatments with fungicides presented above average values for cv. 'BMX Lança', which is approximately $177 \mathrm{~g}$ (BRASMAX, 2018), in comparison with the control (176.2 g), thus evidencing the beneficial effect of fungicide application on the thousand grains weight.

According to Almeida et al. (2017) an increase of up to $10 \%$ in thousand grains weight (g) on soybean genotypes (A 4910 RG; BMX Apolo RR; A 6001 RR; Fundacep 55 RR; and Coodetec 214 RR) that received systemic fungicides (azoxystrobin + cyproconazole; or piraclostrobin + epoxiconazole), realized at: i) pre-closing between lines and at 21 days after closing; ii) pre-closing between lines and at stage R5.1; and iii) at stages R1 and R5.1.

Still regarding the thousand grains weight, in the 2017/18 crop, it can be observed that there was a reduction when compared to the previous crop season (Table 2). This can be explained by the period of water stress at the beginning of the establishment of the crop (stage v2), as it is at this moment that its yield components begin to be defined. It is noteworthy that soybean is sensitive to drought at the beginning of the cycle. This causes a reduction in the emission of new branches and, consequently, reflects on the number of nodes that would produce pods, affecting crop yield (GAVA et al., 2016).

For the grain yield, in the 2016/17 crop, treatments $\mathrm{A}+\mathrm{B}, \mathrm{T}+\mathrm{P}+\mathrm{Mb}, \mathrm{A}+\mathrm{B}+\mathrm{Mb}$ and $\mathrm{Mb}$ differed statistically from the $2017 / 18$ crop (Table 2), corroborating with Silva et al. (2015), in which the multisite mancozeb, applied four and five times, at doses of 2.0 and $1.5 \mathrm{~kg} \mathrm{ha}^{-1}$, provided better control of Asian soybean rust. 
Table 2. Number of pods per plant, weight of thousand grains $\left(\mathrm{g}^{-1}\right)$ and yield $\left(\mathrm{kg} \mathrm{ha}^{-1}\right)$, according to the application of systemic fungicides, combined or not with multisite mancozeb, for the control of Asian soybean rust, cv. 'BMX Lança', in the 2016/17 and 2017/18 crop seasons.

\begin{tabular}{|c|c|c|c|c|c|c|}
\hline \multirow{3}{*}{ Treatments } & \multicolumn{6}{|c|}{ Crop Seasons } \\
\hline & $2016 / 17$ & $2017 / 18$ & $2016 / 17$ & $2017 / 18$ & $2016 / 17$ & $2017 / 18$ \\
\hline & \multicolumn{2}{|c|}{$\begin{array}{c}\text { Number of pods per } \\
\text { plant }\end{array}$} & \multicolumn{2}{|c|}{$\begin{array}{l}\text { Thousand grain weight } \\
\qquad\left(\mathrm{g}^{-1}\right)\end{array}$} & \multicolumn{2}{|c|}{$\begin{array}{c}\text { Yield } \\
\left(\mathrm{kg} \mathrm{ha}^{-1}\right) \\
\end{array}$} \\
\hline $\begin{array}{l}\text { Trifloxystrobin + } \\
\text { prothioconazole }\end{array}$ & $46.9^{\mathrm{ns}} B^{1}$ & $71.4^{\mathrm{ns}} \mathrm{A}$ & 190.6 aA & $140.0 \mathrm{abB}$ & $3589.2 \mathrm{bcA}$ & $3643.4 \mathrm{abA}$ \\
\hline $\begin{array}{l}\text { Azoxystrobin }+ \\
\text { benzovindiflupyr }\end{array}$ & $55.0 \mathrm{~A}$ & $69.0 \mathrm{~A}$ & $187.7 \mathrm{abA}$ & $137.6 \mathrm{abB}$ & $4319.2 \mathrm{abA}$ & $3356.6 \mathrm{abcB}$ \\
\hline $\begin{array}{l}\text { Trifloxistrobin + } \\
\text { prothioconazole + mancozeb }\end{array}$ & $43.0 \mathrm{~B}$ & $68.3 \mathrm{~A}$ & $199.8 \mathrm{aA}$ & $144.6 \mathrm{aB}$ & $4490.2 \mathrm{aA}$ & $3874.4 \mathrm{aB}$ \\
\hline $\begin{array}{l}\text { Azoxystrobin }+ \\
\text { benzovindiflupyr }+ \\
\text { mancozeb }\end{array}$ & $43.3 \mathrm{~B}$ & $60.5 \mathrm{~A}$ & 198.7 aA & $138.5 \mathrm{abB}$ & $3994.6 \mathrm{abA}$ & $3412.3 \mathrm{abcB}$ \\
\hline Mancozeb & $45.9 \mathrm{~B}$ & $76.3 \mathrm{~A}$ & $186.6 \mathrm{abA}$ & $129.2 \mathrm{bB}$ & $4129.1 \mathrm{abA}$ & 2858.2 cB \\
\hline Control & $39.9 \mathrm{~B}$ & $58.3 \mathrm{~A}$ & $176.2 \mathrm{bA}$ & $126.5 \mathrm{bB}$ & $2869.4 \mathrm{cA}$ & $3098.5 \mathrm{bcA}$ \\
\hline C.V. $(\%)^{2}$ & \multicolumn{2}{|c|}{18.3} & \multicolumn{2}{|c|}{3.9} & \multicolumn{2}{|r|}{9.9} \\
\hline
\end{tabular}

Additionally, the treatment with trifloxystrobin + prothioconazole + mancozeb $(\mathrm{T}+\mathrm{P}+\mathrm{Mb})$ stood out for yield in the two crop seasons in which the work was conducted (Table 2). In 2016/17 crop, the addition of mancozeb to the systemic fungicide resulted in a productivity increase of $900 \mathrm{~kg} \mathrm{ha}^{-1}$ when compared to the systemic fungicide applied isolate (Table 2).

This reinforces the importance of the use of systemic fungicides combined with multisite, in the control of Asian soybean rust, as this practice is a tool for the management of Phakopsora pachyrhizi resistance, preserving the efficacy and extending the useful life of fungicides acting on specific sites (DMIs, Qols and SDHIs) (SILVA et al., 2015).

\section{Conclusions}

The combination of systemic fungicides and mancozeb $(\mathrm{T}+\mathrm{P}+\mathrm{Mb}$ - trifloxystrobin + prothioconazole + mancozeb; and $\mathrm{A}+\mathrm{B}+\mathrm{Mb}$ azoxystrobin + benzovindiflupyr + mancozeb), causes reduction in the severity and the progress of Asian soybean rust, cv. 'BMX Lança', with control over $81 \%$.

The treatment with trifloxystrobin + prothioconazole + mancozeb is effective in controlling Asian rust and increases soybean yield by up to $900 \mathrm{~kg} \mathrm{ha}^{-1}$ compared to systemic fungicide applied alone.

\section{Acknowledgements}

The authors acknowledge to the Fundação de Amparo à Pesquisa do Estado do Rio Grande do Sul (FAPERGS) for granting scientific initiation scholarships (PROBIC and PROBITI) to the first, third and fourth authors, and to the Universidade Federal da Fronteira Sul (UFFS) for granting scientific initiation scholarships (PRO-ICT) to the second and the fifth authors.

\section{References}

ALMEIDA, R.; FORCELINI, C. A.; GARCÉS-FIALLOS, F. R. Chemical control of foliar diseases in soybean depends on cultivar and sowing date. Bioscience Journal, v. 33 , n. 5, p. 1188-1196, 2017. http://doi.org/10.14393/BJ-v33n5a2017$\underline{36931}$

AZEVEDO, L. A. S. Misturas de tanque de produtos fitossanitários: teoria e prática. Rio de Janeiro: IMOS, 2015.

BRASIL. Ministério da Agricultura, Pecuária e Abastecimento. Regras para análise de sementes. Brasília: Mapa/ACS, 2009. 
BRASMAX GENÉTICA. Cultivar Brasmax Lança IPRO. Paraná: Brasmax, 2018. Disponível em: http://www.brasmaxgenetica.com.br/cultivarregiao-sul/?produto=1113. Acesso em: 23 out. 2018.

CAMPBELL, C. L.; MADDEN, L. V. Introduction to plant disease epidemiology. New York: John Wiley \& Sons, 1990.

EMBRAPA. Eficiência de fungicidas para o controle da ferrugem asiática da soja, Phakopsora pachyrhizi, na safra 2012/13: resultados sumarizados dos ensaios cooperativos. Londrina: Embrapa Soja, 2013a. 8 p. (Série Embrapa Soja. Circular técnica, 93).

EMBRAPA. Tecnologias de produção de soja: região Central do Brasil 2014. Londrina: Embrapa Soja, 2013b. Disponível em: http://ainfo.cnptia.embrapa.br/digital/bitstream/ item/95489/1/SP-16-online.pdf. Acesso em: 16 maio 2018.

EMBRAPA. Eficiência de fungicidas para o controle da ferrugem-asiática da soja, Phakopsora pachyrhizi, na safra 2013/14: resultados sumarizados dos ensaios cooperativos. Londrina: Embrapa Soja, 2014. 7 p. (Série Embrapa Soja. Circular técnica, 103). Disponível em:

https://ainfo.cnptia.embrapa.br/digital/bitstream item/107820/1/CT103-online.pdf. Acesso em: 12 oct. 2018.

EMBRAPA. Eficiência de fungicidas para o controle da ferrugem-asiática da soja, Phakopsora pachyrhizi, na safra 2015/16: resultados sumarizados dos ensaios cooperativos. Londrina: Embrapa Soja, 2016a. 6 p. (Série Embrapa Soja. Circular técnica, 119). Disponível em:

https://ainfo.cnptia.embrapa.br/digital/bitstream item/146405/1/CT119-OL.pdf. Acesso em: 12 oct. 2018.

EMBRAPA. Eficiência de fungicidas multissítios no controle da ferrugem-asiática da soja, Phakopsora pachyrhizi, na safra 2015/16: resultados sumarizados dos ensaios cooperativos.
Londrina: Embrapa Soja, 2016b. 7 p. (Série Embrapa Soja. Circular técnica, 121). Disponível em:

https://ainfo.cnptia.embrapa.br/digital/bitstream item/147677/1/CT-121.pdf. Acesso em: 12 oct. 2018.

EMBRAPA. Sistema brasileiro de classificação de solos. Brasília: Embrapa, 2018.

FERREIRA, D. F. Sisvar: a computer statistical analysis system. Ciência e Agrotecnologia, v. 35, n. 6, p. 1039-1042, 2011.

http://dx.doi.org/10.1590/S1413-

$\underline{70542011000600001}$

FIGUEIREDO, G. V. C; FANTIN, L. H.; CANTERI, M. G.; ROCHA, J.C. F.; JACCOUD FILHO, D. S. A Bayesian Probability Model Can Simulate the Knowledge of Soybean Rust Researchers to Optimize the Application of Fungicides. International Journal of Agricultural and Environmental Information Systems, v. 10, n. 4, p. 37-51, 2019.

http://dx.doi.org/10.4018/IJAEIS.2019100103

FUNGICIDE RESISTANCE ACTION COMMITTEE (FRAC). SDHI working group: informações sobre carboxamidas em ferrugem da soja. [S.I.]: FRAC, 2017. 3 p. Disponível em:

http://docs.wixstatic.com/ugd/85b1d3 060a687 6562140b693f03708057acff2.pdf. Acesso em: 16 jul. 2019.

GAVA, R.; FRIZZONE, J. A.; SNYDER, R. L.; ALMEIDA, B. M.; DE FREITAS, P. S. L.; REZENDE, R. Estratégias de manejo de déficit hídrico na irrigação da cultura da soja. Brazilian Journal of Biosystems Engineering, v. 10, n. 3, p. 305-315, 2016.

http://dx.doi.org/10.18011/bioeng2016v10n3p30 $\underline{5-315}$

GODOY, C. V.; KOGA, L. J.; CANTERI, M. G. Diagrammatic scale for assessment of soybean rust severity. Fitopatologia Brasileira, v. 31, n. 1, p. 63-68, 2006. http://dx.doi.org/10.1590/S0100$\underline{41582006000100011}$

GODOY, C. V.; SEIXAS, C. D. S.; SOARES, R. M.; MARCELINO-GUIMARÃES, F. C.; MEYER, M. C.; COSTAMILAN, L. M. Asian soybean rust in Brazil: 
past, present, and future. Pesquisa Agropecuária Brasileira, v. 51, n.5, p. 407-421, 2016. http://dx.doi.org/10.1590/S0100$\underline{204 \times 2016000500002}$

JULIATTI, F. C.; POLLONI, L. C.; PRADO, T. M.; ZACARIAS, N. R. S.; SILVA, E. A.; JULIATTI, B. C. M. Sensitivity of Phakopsora pachyrhizi populations to dithiocarbamate, chloronitrile, triazole, strobilurin, and carboxamide fungicides. Bioscience Journal, v. 33, n. 4, p. 933-943, 2017. http://doi.org/10.14393/BJ-v33n4a2017-38357

KNEBEL, D. F.; SILVA, D. R. O.; DEMARI, G. H.; CARVALHO, I. R., SZARESKI, V. J.; SANTOS, L. A.; LAUTENCHLEGER, F. Economic efficiency and soybean yield due to the use of different fungicide combinations. Plant Omics, v. 12, n. 1, p. 9-14, 2019. 10.21475/poj.12.01.19.pt1156

KLOSOWSKI, A. C.; MAY DE MIO, L. L.; MIESSNER, S.; RODRIGUES, R.; STAMMLER, G. Detection of the F129L mutation in the cytochrome $b$ gene in Phakopsora pachyrhizi. Pest Management Science, v. 72, n. 6, p. 1211-1215, 2016. http://doi.org/10.1002/ps.4099

LANGENBACH, C.; CAMPE, R.; BEYER, S. F.; MUELLER, A. N.; E CONRATH, U. Fighting Asian soybean rust. Frontiers in Plant Science, v. 7, n. 1, p. 797, 2016.

http://doi.org/10.3389/fpls.2016.00797

LEMES, E.; CASTRO, L.; ASSIS, R. Doenças da soja: melhoramento genético e técnicas de manejo. Campinas: Millennium, 2015.

MATZENAUER, R.; RADIN, B.; ALMEIDA, I., R. (Ed.). Atlas climático: Rio Grande do Sul. Porto Alegre: Secretaria da Agricultura Pecuária e Agronegócio: Fundação Estadual de Pesquisa Agropecuária (FEPAGRO), 2011.

MINCHIO, C. A.; FANTIN, L. H.; CAVIGLIONE, J. H.; BRAGA, K.; SILVA, M. A. A. E.; CANTERI, M. G. Predicting Asian soybean rust epidemics based on off-season occurrence and EI Niño southern oscillation phenomenon in Paraná and Mato Grosso states, Brazil. Journal of Agricultural Science, v. 10, n. 11, p. 562-572. 2018. https://doi.org/10.5539/jas.v10n11p562
REIS, E. M.; REIS, A. C.; CARMONA, M. A. Manual de fungicidas: guia para o controle químico racional de doenças de plantas. Passo Fundo: Berthier, 2016.

REIS, E. M.; CARREGAL, L. H.; ZANATTA, M. Comparison of the efficacy of Qol fungicides, alone or in mixture with triazoles, in Asian soybean rust control, 2016/17 growing season. Summa Phytopathologica, v. 45, n. 1, p. 28-32, $2019 . \quad$ http://dx.doi.org/10.1590/0100$\underline{5405 / 190157}$

SCHMITZ, H. K.; MEDEIROS, C. A.; CRAIG, I. R.; STAMMLER, G. Sensitivity of Phakopsora pachyrhizi towards quinone-outside-inhibitors and demethylation-inhibitors, and corresponding resistance mechanisms. Pest Management Science, v. 70, n. 3, p. 378-388, 2014. http://doi.org/10.1002/ps.3562

SILVA, L. H. C. P. D.; CAMPOS, H. D.; SILVA, J. R. C.; REIS, E. M. Control of Asian soybean rust with mancozeb, a multi-site fungicide. Summa Phytopathologica, v. 41, n. 1, p. 64-67, 2015. http://dx.doi.org/10.1590/0100-5405/1957

TAIZ, L.; ZEIGER, E. Fisiologia vegetal. 5. ed. Porto Alegre: Artmed, 2013. 